Research Article

\title{
Responsible Research and Innovation (RRI): Scientometric Analysis
}

\section{Investigación e Innovación Responsables (RRI): Análisis Cienciométrico}

\author{
Akbar Mohammadi \\ University of Tehran \\ Correspondence: imohammadi@ut.ac.ir
}

\begin{abstract}
Innovation and research in various fields should be done responsibly. In the last years, there is this responsibility towards different stakeholders. One of the most important stakeholders are the community and the society. In this context, the concept of social responsibility and social innovation has become very widespread. The purpose of this study was scientometric analysis of concepts in the field of responsible innovation and responsible research. $\mathrm{R}$ software has been used to achieve this purpose. In this study, by analyzing the information extracted from related articles ( 572 articles from Web of Science), the new concept of RRI and the network of researchers in this regard have been identified and analyzed. In this study, based on a systematic literature review (SLR) and scientometric methods, the evolution of the concept of "Responsible Research" and "Responsible Innovation" in the literature is investigated. Also, the selected articles identified by the SLR method from different textual dimensions regarding journals, collaboration network, co-citation network, collaboration worldmap, historical direct citation network, and emergence of new concepts are analyzed. The results of this study indicate the development of related concepts in the literature in recent years and indicate the need for further studies in this regard.
\end{abstract}

Keywords: Responsible Research and Innovation (RRI); scientometric analysis; responsible research; responsible innovation; Web of Science (WOS).

Resumen: La innovación y la investigación en diversos campos deben realizarse con responsabilidad. En los últimos años, existe esta responsabilidad hacia las diferentes partes interesadas. Una de las partes interesadas más importantes es la comunidad y la sociedad. En este contexto, el concepto de responsabilidad social e innovación social se ha extendido mucho. El objetivo de este estudio es realizar un análisis cienciométrico de ambos conceptos en el ámbito de la innovación responsable y la investigación responsable. Para ello, se ha utilizado el software R. En este estudio, mediante el análisis de la información extraída de los artículos relacionados (572 artículos de Web of Science), se ha identificado y analizado el nuevo concepto de RRI y la red de investigadores al respecto. Basado en una revisión sistemática de la literatura (SLR) y en métodos cienciométricos, se investiga la evolución del concepto de "Investigación Responsable" e "Innovación Responsable" en la literatura. Asimismo, se analizan los artículos seleccionados e identificados por el método SLR a partir de diferentes dimensiones textuales relativas a las revistas, la red de colaboración, la red de citación conjunta, el mapa mundial de colaboración, la red de citación directa histórica y la aparición de nuevos conceptos. 
Los resultados de este estudio indican el desarrollo de conceptos relacionados en la literatura en los últimos años y señalan la necesidad de realizar más estudios al respecto.

Palabras clave: Investigación e innovación responsables (RRI); análisis cienciométrico; investigación responsable; innovación responsable; Web of Science (WOS).

\section{Introduction}

Exploring the concepts of responsible innovation and responsible research in the literature brings us to a new concept that has emerged in recent years. This is the concept of Responsible Research and Innovation (RRI). Responsible research and innovation is a transparent and interactive process in which actors and innovators of society are held accountable based on acceptance (ethical), sustainability and social desirability, based on the process of innovation and marketable products (René Von Schomberg, 2012; Rene Von Schomberg, 2013). While the origins of RRI date back to the early 1990s, the concept has received a great deal of attention since 2011 in the EU's policy and research communities (Owen, Macnaghten \& Stilgoe, 2012). Responsive Innovation (RI) and Responsive Research and Innovation (RRI) have emerged in recent years as the most important issues in the relationship between innovation and research with society (Stilgoe \& Guston, 2017; Thapa, Iakovleva \& Foss, 2019). Rocco et al. (2011) listed four characteristics of responsible innovation as: (1) changes in existing arrangements, (2) consideration of equitable access, health, safety, and environmental concerns, (3) partnerships between government agencies, and other stakeholders and (4) long-term measures for anticipation and compliance (Roco et al., 2011). The concept of RRI has been challenged by discourses on emerging technologies and research ethics in innovative fields (Owen et al., 2012) It has been driven by EU's research and innovation policy over the past few years (Auer \& Jarmai, 2018). RRI can be considered as a concept that has been developed to expand the scope of policymaking, to show the path of innovation and to determine the role of actors in society (Burget, Bardone \& Pedaste, 2017; Levidow \& Neubauer, 2014). The concept of RRI is an attempt to promote a new method of governance in the direction of research and innovation. This method has been described as "a way to think more systematically about the general benefits of scientific and technological research." (Baldwin et al., 2013; Timmermans et al., 2017).

After the concept of entrepreneurship was added to scientific and research centers in science and technology studies in completing educational and research functions, we are witnessing a new paradigm shift in recent years. The responsibility paradigm seeks to be a suitable replacement for the entrepreneurial paradigm. In the entrepreneurship paradigm, research and technology are committed to improving the state of industry and society (Babaei \& Tavakkoli, 2015). That is, research should be conducted in a way that increases the productivity and efficiency of the market and the production capacity of artisans and reduces the problems of society (Babaei \& Tavakkoli, 2017). But in the paradigm of responsibility of research and innovation, researchers' commitments to social values and environmental considerations are evident. For example, concepts such as safety, justice and sustainability in this paradigm play a more prominent role in researchers 'studies and policy makers' decisions (Mohammadi \& Mohammadi, 2021).

In this study, based on a systematic literature review (SLR) and scientometric methods, the evolution of the concept of RRI in the literature is investigated. Also, the selected articles identified by the SLR method from different textual dimensions regarding journals, collaboration network, co-citation network, collaboration worldmap, historical direct citation network, and emergence of new concepts are analyzed. The paper concludes with an account of the theoretical 
contribution and managerial implications of our study for innovative responsibility activities and practices.

\section{Literature Review}

There are several definitions of the main factors of RRI discourse. For example, the broad definition offered by von Schomberg (2013) is closely related to the trends and values set out in EU policies (Stilgoe, Owen \& Macnaghten, 2013). Von Schomberg defined RRI as "a design strategy that drives innovation and achieves the desired goals of society" (von Schomberg, 2013). Most researchers in the definition of RRI have emphasized von Schomberg's definition (Bremer et al., 2015; Forsberg et al., 2015). However, several other authors have provided their definition of RRI. Most of them who have given academic definitions of RRI have mentioned public engagement as a vital part of RRI. Other dimensions and aspects such as foresight, responsiveness, reflectivity, desirability, acceptability and innovation are sometimes mentioned (Burget et al., 2017). Stahl (2013) considers RRI as a trans-responsibility that defines the concept as follows:

"RRI is a macro-level responsibility or trans-responsibility that aims to shape, maintain, develop, coordinate and align existing and new processes related to research and innovation, actors and responsibilities in order to ensure desirable and acceptable research results"

RRI explicitly addresses issues of social development, social justice, and the extension of STI benefits. However, it is rarely articulated about these concepts in the subject literature (Ribeiro et al., 2018). Responsible Research and Innovation emphasize the importance of governance in innovation process (especially in the field of key stakeholders' interaction and the need for inclusive and sustainable development) in the field of regional development (Thapa et al., 2019). Another important definition stems from another policy document issued in 2013 (p. 3) by the European Commission entitled "Options for strengthening responsible research and innovation". In recent years, another comprehensive definition has been provided as follows:

RRI is a policy-driven discourse that has been grounded in the European Commission (EC) since 2011. At the macro level, its goal is to foster a comprehensive and sustainable research and innovation plan, with an emphasis on co-creation with society. "Science with society and for society" (Owen \& Pansera, 2019).

Based on the EU's RRI Framework for Horizon 2020, RRI became a formal issue, and project funding began in the Science for Society program (now known as Science for and by Society). Therefore, in 2014, the mainstream RRI was introduced throughout the EU region through the "Rome Declaration on RRI" project (Thapa et al., 2019).

The EU demonstrated its commitment to RRI through a number of related measures (including funding a program of research support and coordination activities under the Fourth Plan (FP7) in the Horizon 2020 project) and formed a committee to promote RRI-related programs in 2011. After that, in 2012, the EU Commissioner for Research, Innovation and Science Maire Geoghegan-Quinn formally announced her support for EU RRI policies. The EU's recent "Open Global Interaction" agenda in partnership with non-European countries is also on the RRI discourse (Owen \& Pansera, 2019). However, beyond Europe, there is a relative awareness of the concept of RRI in emerging global economies (Brazil, India and China) as well as in some advanced economies (Japan, Australia) (Brom et al., 2015).

If the RRI is to be considered as a concept recognized in other countries and other research initiatives and fields, it must be able to take significant relevant action. Participating and interacting with global science and technology actors and their distinct needs can work for nations where the RRI discourse is underdeveloped and not considered a priority. To be able to make innovation and research transparent and responsible (Macnaghten et al., 2014). The European Commission described six distinct dimensions termed as follows: engagement, gender equality, science education, ethics, open access and governance (Regulation (EU) No 1291/2013, 
2013). Of course, the concept of ethics and some other related issues in science, technology, research and innovation is not a new topic in general, but the concept of RRI has recently been introduced to include responsibility in research and innovation policies and methods (Flick, 2016; Stilgoe et al., 2013; von Schomberg, 2011). Stahl (2013) focused his research on the practical implementation of the dimensions that arise for actors, norms, and activities. Stilgoe et al, proposed a broader definition of RRI 'taking care of the future through collective stewardship of science and innovation in the present' in 2013 (Stilgoe et al., 2013:1517). Various authors have referred to previous dimensions that were not originally associated with RRI (Stahl, 2013). Stilgoe et al. (2013) mentioned four dimensions that were raised during the general debates: anticipation, inclusion, reflexivity, and responsiveness. This framework for RRI focuses on four integrated dimensions (Stilgoe et al., 2013) This classification was adapted and adopted by the UK Engineering and Physical Sciences Research Council to form the AREA (anticipation, reflection, engagement and action) framework (Owen, 2014).

\section{Methodology}

In this paper, a comprehensive scientometric study in the field of responsible research and responsible innovation has been conducted. In the first step, ISI papers in related fields were extracted from the WOS database. In the next step, after initial screening and identification of related articles in terms of title, abstract and content, the final articles were analyzed based on an analytical-process package called "Bibliometrix" in R software. This analytical-process package is a tool for quantitative research in the field of scientometrics that is used for statistical analysis of articles extracted from citation databases. These statistical analyzes that have been used in this study have been in the fields of analysis of scientific collaborations of researchers, co-citation and synergies between scientific activities. These statistical analyzes have been performed on scientific collaborations of researchers, co-citations and synergies between scientific activities (Aria \& Cuccurullo, 2017).

In the first search on the Web of Science citation database, the keywords "Responsible Research" and "Responsible Innovation" were searched. 861 articles were identified in English between 1990 and 2021. Then, in the first screening step, 648 articles were selected based on the subject area and journals. Also, in the next screening, from the perspective of reviewing the title and abstract, 572 articles were finally selected for scientometric analysis in the field of responsible research and responsible innovation.

Figure 1. Flow diagram of article selection.

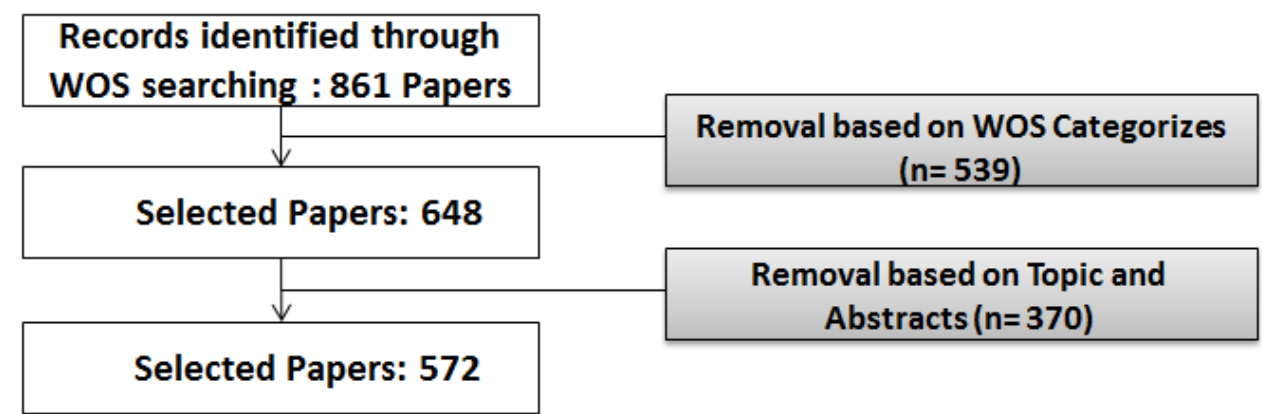

Source: Author's elaboration.

Scientometrics is a tool for quantitative analysis and statistical evaluation of documents such as journal papers and the number of citations. Today, these analytical methods are used to assess the growth rate of concepts, leading authors, and the mind and concept maps of research. These tools can also be used to identify the evolution of scientific societies and evaluate research performance in various fields. The existence of effective statistical algorithms, access to quality 
numerical routines as well as integrated information imaging tools are the most important qualitative features that make researchers prefer $\mathrm{R}$ programming language to other languages for scientific computing (Aria \& Cuccurullo, 2017).

\subsection{Descriptive statistics of selected articles}

Based on the results of scientific search and screenings, the descriptive statistical information of the selected papers is presented in Table1:

Table 1. The descriptive statistical information of the selected papers.

\begin{tabular}{cc}
\hline Description & \\
\hline Articles & 572 \\
Period & $1990: 2021$ \\
Average citations per documents & 11.22 \\
Authors & 2037 \\
Author Appearances & 2411 \\
Authors of single authored documents & 121 \\
Authors of multi authored documents & 1916 \\
Documents per Author & 0.284 \\
Authors per Document & 3.52 \\
Co-Authors per Documents & 4.17 \\
Collaboration Index & 4.3 \\
\hline
\end{tabular}

Source: Author's elaboration.

As shown in Table 1, based on scientometric analysis, 572 selected articles of this research were analyzed. Indicators of mean citation and co-authorship are also expressed. Figure 2 shows the annual production trend of articles over a period of time. As can be seen in the figure, the upward trend in science production in the field of responsible innovation and research is very evident.

Figure 2. The WOS selected publications on the analysis of responsible research and responsible innovation from 1990 to 2021.

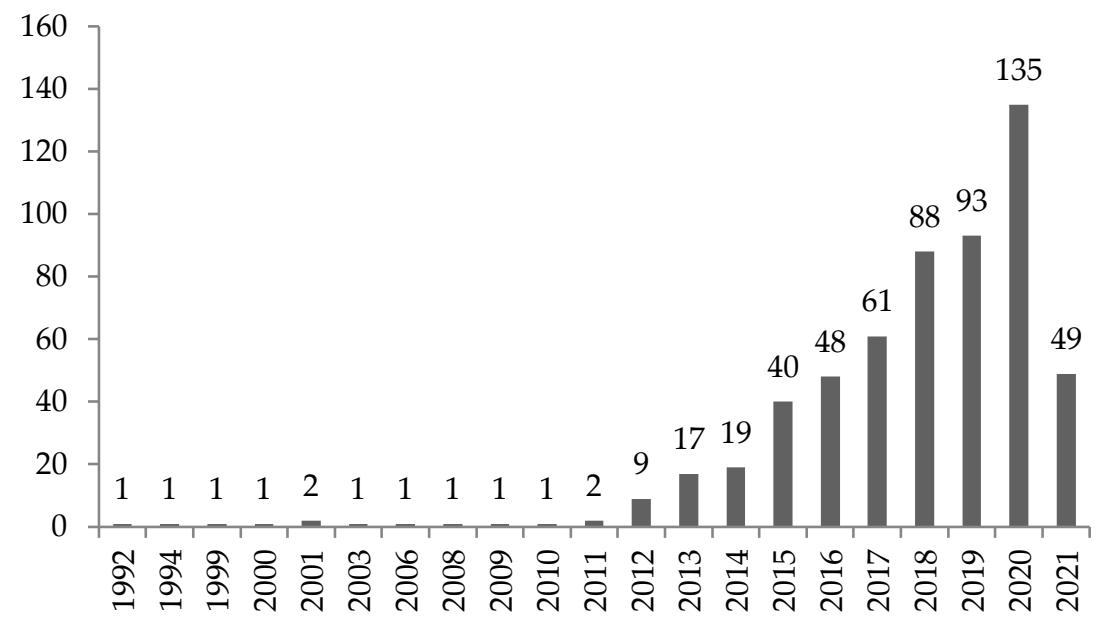

Source: Author's elaboration.

In Table 2, the 10 most referenced articles are ranked. Also, their average annual citation for each article is stated. 
Table 2. Descriptive analysis: Top 10-Most cited papers.

\begin{tabular}{lcc}
\hline \multicolumn{1}{c}{ Paper } & Total Citations & TC per Year \\
\hline STILGOE J, 2013, RES POLICY & 718 & 79.7778 \\
OWEN R, 2012, SCI PUBL POLICY & 492 & 49.2 \\
YANG GZ, 2018, SCI ROBOT & 177 & 44.25 \\
SOM C, 2010, TOXICOLOGY & 139 & 11.5833 \\
DONDORP W, 2015, EUR J HUM GENET & 131 & 18.7143 \\
FLEMING AJ, 2007, LARYNGOSCOPE & 107 & 7.1333 \\
GERGEN KJ, 2015, AM PSYCHOL & 98 & 14 \\
HALME M, 2014, BUS STRATEG ENVIRON & 93 & 11.625 \\
BOGOUSSLAVSKY J, 2003, STROKE & 89 & 4.6842 \\
PIDGEON N, 2013, NAT CLIM CHANGE & 76 & 8.4444 \\
\hline
\end{tabular}

Source: Author's elaboration.

Out of 572 selected articles, 94 are related to the journal entitled: "JOURNAL OF RESPONSIBLE INNOVATION". The 10 journals with the most selected articles in the field of social innovation and social responsibility are listed in Table 3 along with the number of articles included.

Table 3. The 10 journals with the most selected articles in the field of social innovation and social responsibility.

\begin{tabular}{lc}
\hline \multicolumn{1}{c}{ Sources } & Articles \\
\hline JOURNAL OF RESPONSIBLE INNOVATION & 94 \\
SCIENCE AND ENGINEERING ETHICS & 38 \\
SUSTAINABILITY & 33 \\
NANOETHICS & 29 \\
SCIENCE AND PUBLIC POLICY & 12 \\
TECHNOLOGICAL FORECASTING AND SOCIAL CHANGE & 10 \\
RESEARCH POLICY & 9 \\
ETHICS AND INFORMATION TECHNOLOGY & 8 \\
JOURNAL OF AGRICULTURAL \& ENVIRONMENTAL ETHICS & 8 \\
SCIENCE TECHNOLOGY AND SOCIETY & 8 \\
\hline
\end{tabular}

Source: Author's elaboration.

The results of reviewing the references of 572 selected articles showed that 724 referenced articles were from the journal entitled: "JOURNAL OF RESPONSIBLE INNOVATION". There are also 619 articles cited in the journal entitled: "Research Policy". Table 4 shows the journals with the most citations. 
Table 4. The 10 journals with the most selected articles in the field of social innovation and social responsibility.

\begin{tabular}{|c|c|}
\hline Sources & Articles \\
\hline J RESPONSIBLE INNOV & 724 \\
\hline RESPONSIBLE INNOVATI & 640 \\
\hline RES POLICY & 619 \\
\hline SCI ENG ETHICS & 450 \\
\hline SCI PUBL POLICY & 409 \\
\hline NATURE & 313 \\
\hline SCI TECHNOL HUM VAL & 312 \\
\hline SUSTAINABILITY-BASEL & 264 \\
\hline PUBLIC UNDERST SCI & 262 \\
\hline TECHNOL FORECAST SOC & 256 \\
\hline
\end{tabular}

Source: Author's elaboration.

There are various software tools that help researchers analyze scientometrics, but some of them are much more widely used. Among them can be software tools are Biblioshiny (Runs in R, 2019) (Moral Muñoz et al., 2020), BiblioMaps (Runs in Python, 2018) (Moral Muñoz et al., 2020), CitNetExplorer (Van Eck \& Waltman, 2014), VOSviewer (Van Eck \& Waltman, 2010), SciMAT (Cobo et al., 2012), BibExcel (Persson, Danell \& Schneider, 2009), Science of Science (Sci2) Tool (Team, 2009) and CiteSpace (Chen, 2006).

\section{Findings}

Based on the Co-Citation Network, researchers' citation network can be observed in the field of scientific production of responsible innovation and responsible research. Scientific articles of researchers such as Stilgoe (2013), Owen (2012) and Von schomberg (2013) have the highest density in the rate of co-citation in the network. These articles promote strong networks around themselves by presenting the basis of scientific discussions on innovation and responsible research.

Figure 3. Co-Citation Network.

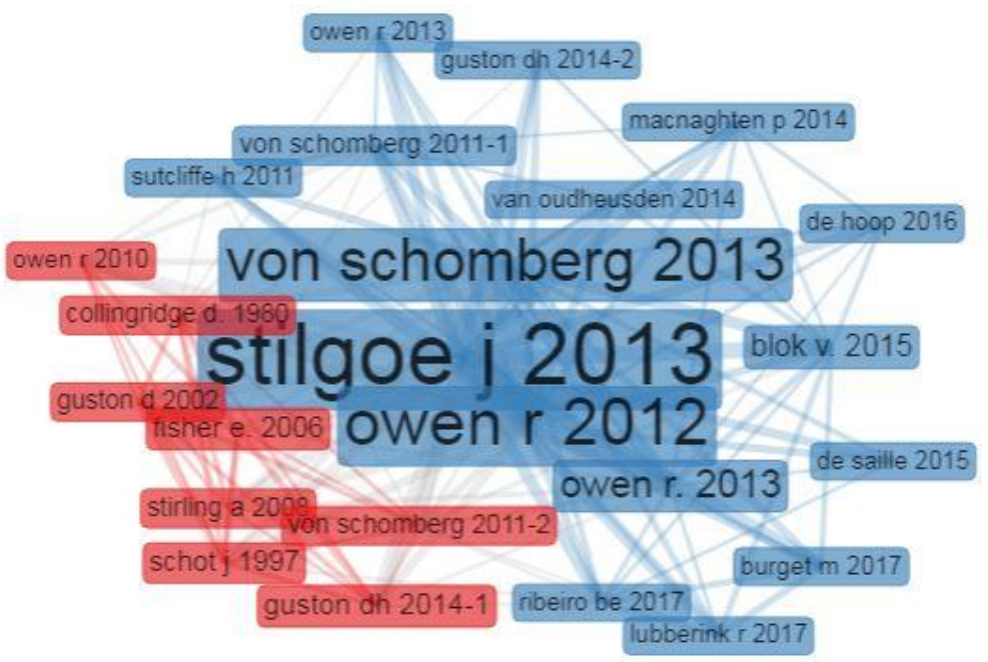

Source: Author's elaboration. 
Figure 4. Researcher's Collaboration Network.

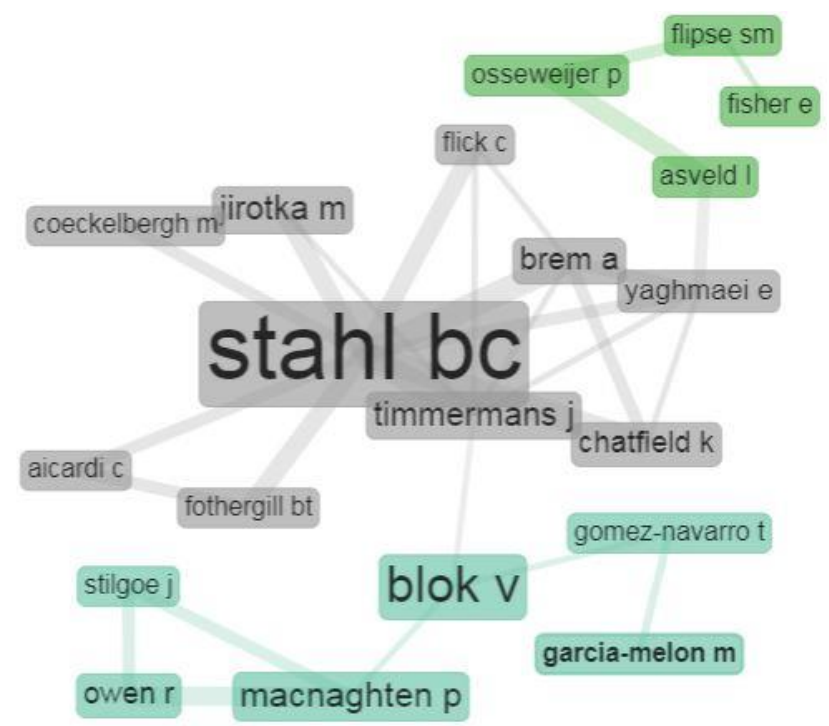

Source: Author's elaboration.

Figure 3 shows the network of collaboration between the authors of the articles by analyzing 572 selected articles. As can be seen in the figure, Stahl bc was able to create the largest network of scientific production cooperation in this scientific field. In this regard, Blok v and Yaghmaei, who are also known as Stahl co-authors in articles, have been able to feed other scientific networks as scientific mediators. Based on Figure 4, in the last decade, Stahl bc has been able to present the most cited scientific papers in the field of responsible innovation and responsible research. Next to him are Blok v and Lehoux P.

Figure 5. Top-Authors Production over the Time.

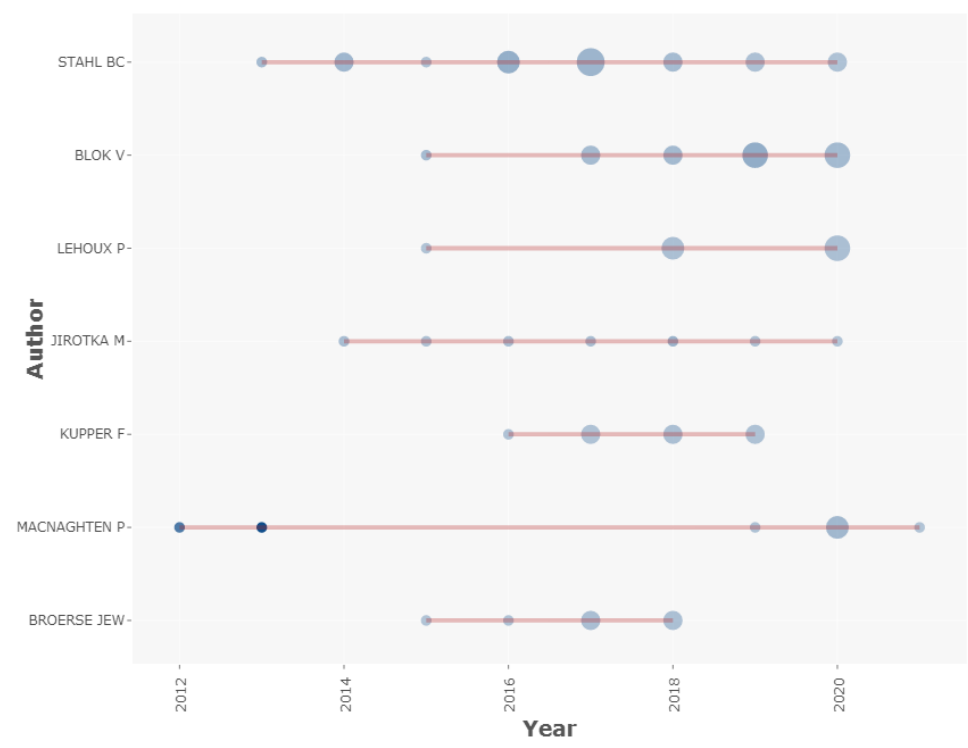

Source: Author's elaboration.

Figure 6 shows the countries that have the most citations in scientific products in the field of responsible innovation and responsible research. As we can see from the results of the figure, the beginning and evolution of this concept started with considerable intensity from the European Union and strong cooperation has been formed between European researchers and other 
researchers in the United States, Australia and Canada. It is expected that in the near future, this concept will be given more attention in developing countries, especially Asian countries.

Figure 6. Collaboration Worldmap.

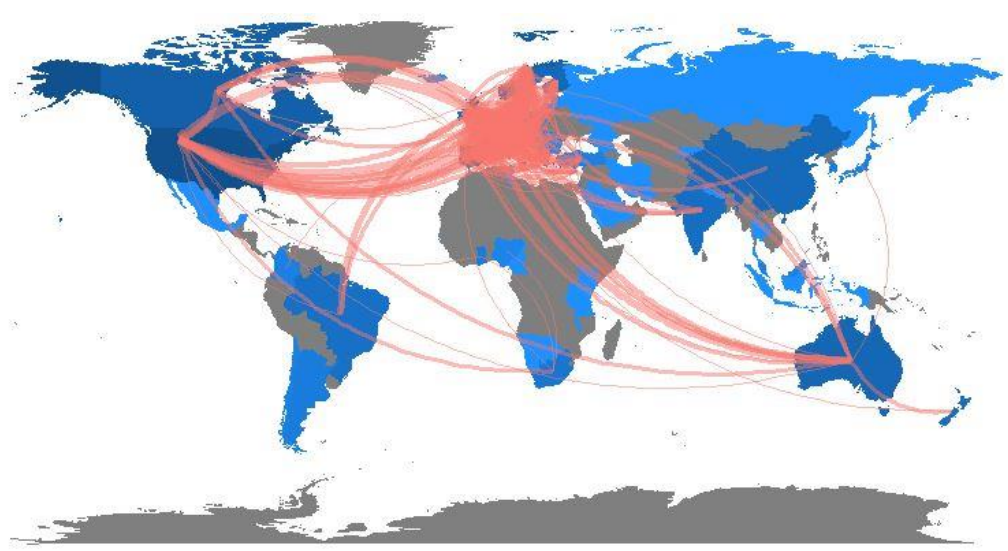

Source: Author's elaboration.

Figure 7 shows the path of science development by various researchers in the field of innovation research and responsible research based on the Historical Direct Citation Network. Based on what we see in the figure, Owen (2010) and Robinson (2009) are known as the basis of the historical chain of production of the relevant sciences. A historiographic map is a graph provided by E. Garfield to represent a chronological network map when it relates to the most direct citations from a bibliographic collection.

Figure 7. Historical Direct Citation Network.

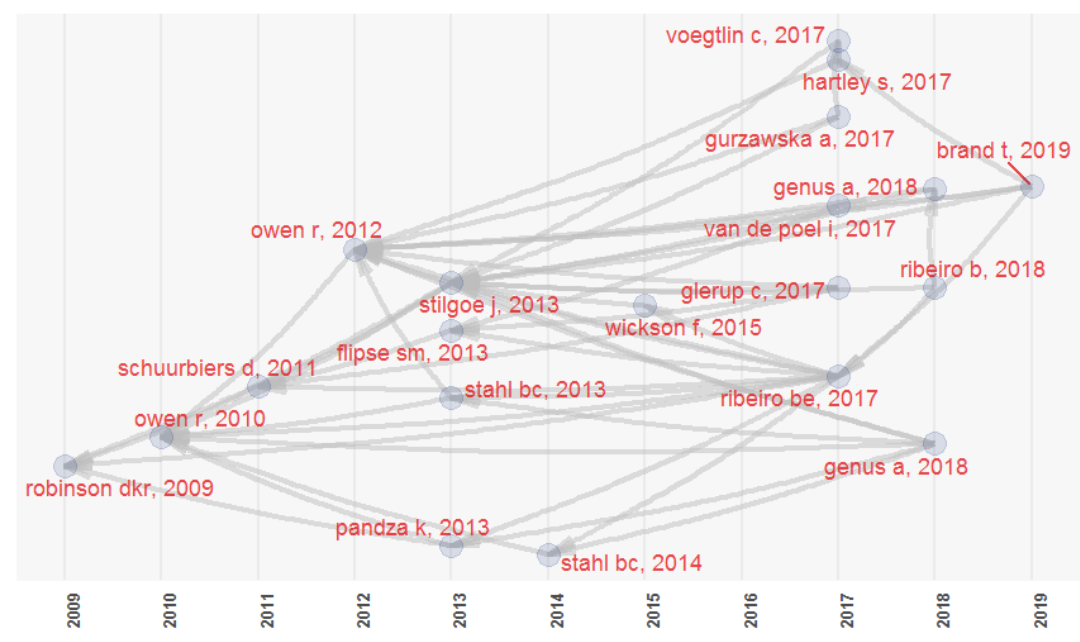

Source: Author's elaboration.

Based on the keyword analysis of 572 selected articles, the results in terms of words occurrence are shown in Table5. The new concept of "Responsible research and innovation" ranks first with 160 repetitions in articles. The keyword "Responsible innovation" has since been repeated 120 times. The keywords "Ethics" and "Governance" are also in the next categories. 
Table 5. Words Occurrence in Selected Papers.

\begin{tabular}{lc}
\hline \multicolumn{1}{c}{ Words } & Occurrences \\
\hline Responsible Research and Innovation & 160 \\
Responsible Innovation & 120 \\
Ethics & 44 \\
Governance & 37 \\
Nanotechnology & 26 \\
\hline
\end{tabular}

Source: Author's elaboration.

\section{Implications}

One of the most important aspects of responsible research and innovation is to create a new model for the Science and technology governance. The main question of the present article is: What are the new scientific concepts and paths for the realization of responsible research and innovation? What are the practical and managerial conditions for the rule of science in the framework of responsible research and innovation? And with what changes can these conditions be met in the governing system of universities? Our research on responsible innovation and responsible research outlines their overall approach to how science's responsibilities take precedence over social, moral, and environmental values. The ultimate goal of the development of this field of literature is to create a common responsible paradigm between science, policymaking and society in all elements of society so that all people can enjoy the benefits of science and technology in a balanced way (European Commission, 2020). One of the most important issues that researchers and policy makers now face is the development of theoretical and creative ideas of responsible research and innovation into practice and the responsibility implementation in the field of research and innovation. This study is also designed to help these researchers and policy makers in clarifying the path of operationalization of ideas to operationalize the responsibility of science and technology. Achieving this goal has been done by reviewing the results presented in recent years in this regard based on scientometric analyzes. Therefore, in order to research and policy in the field of research and responsible innovations, emerging scientific paths have been identified and introduced based on paper analysis. Understanding emerging concepts in the literature can design different and new paths for researchers and policy makers to design patterns and processes for research responsibility. The European Commission has also emphasized the need for new structural, executive and operational perspectives in this regard by introducing the concept of new patterns of scientific governance based on RRI. Accountability of educational and research centers, including universities and research institutes, along with the need for the participation of different sections of society, are general principles that emphasize the creation of new models of governance in responsible research and innovation.

This study has generally been done on the emergence of new concepts and evolution of concepts related to responsible research and innovation. In this article, we have also stated the managerial implications for implementing these concepts in scientific institutions. Examining the challenges of implementing innovation models and responsible research in educational and research institutions and policy making related to them can be considered as complementary axes in future studies. Identifying the mechanisms and processes of implementing RRI and designing appropriate managerial functions is also suggested as future research in this field.

\section{Conclusion}

In the first step of this study, based on the SLR method, identified scientific articles in the field of responsible innovation and responsible research from the WOS database. Then, with screenings and selection of 572 articles, the second step was performed based on the steps of 
analysis using scientometric tools. With the introduction of the above concepts from the European Union in recent years, today, the field of responsible research and innovation has expanded rapidly in developing Asian countries as a growing necessity. This issue should be considered at the academic level as well as the relevant executive levels in different countries. Responsible research and innovation is one of the newest areas that is now widely discussed by researchers in the field of science, technology and innovation studies. Some researchers have introduced this concept as a new paradigm shift in the field of science, technology and innovation studies (De saille, 2015). Our research on responsible innovation and responsible research outlines their overall approach to how science's responsibilities take precedence over social, moral, and environmental values. The ultimate goal of the development of this field of literature is to create a common responsible paradigm between science, policy-making and society in all elements of society so that all people can enjoy the benefits of science and technology in a balanced way (European Commission, 2020).

Responsible Research and Innovation (RRI) refers to a holistic approach that provides the following to the various stakeholders in the early stages of research and innovation processes: A) First, it allows stakeholders to identify relevant knowledge about the consequences of their actions and to consider it in later stages of the investigation. B) Second, it helps stakeholders to effectively evaluate results and options in terms of social needs and ethical values. C) and finally uses the above considerations as functional requirements for the design and development of new research, products and services (Burget et al., 2017).

One of the most important issues in different societies is to determine the appropriate way of governing science and technology to realize the concept of responsible research and innovation. Accountability of universities and research institutes in developing countries, which are mostly government-oriented structures, is one of the challenges. The integration of this concept in the science and technology policy structures of these countries can lead to appropriate paths of development and reduction of society and industry issues. To internalize the values of the concept of responsible research and innovation in universities and research centers, the following policy strategies are proposed:

1) Creating a culture and raising awareness in the field of responsible research and innovation with the help of extension activities.

2) Creating transparency in internal processes and functions in the path of accountability and responsibility.

3) Designing and implementing a system of scientific governance based on accountability and transparency.

4) Appreciation of top researchers and influential scientists in solving the problems of society and industry.

5) Develop a sense of social responsibility in researchers.

6) Supporting activities in the field of Citizen Science.

\section{References}

Aria, M., \& Cuccurullo, C. (2017). bibliometrix: An R-tool for comprehensive science mapping analysis. Journal of informetrics, 11(4), 959-975. https://doi.org/10.1016/j.joi.2017.08.007

Auer, A., \& Jarmai, K. (2018). Implementing responsible research and innovation practices in SMEs: Insights into drivers and barriers from the Austrian medical device sector. Sustainability, 10(1), 17. https://doi.org/10.3390/su10010017

Babaei, S., \& Tavakoli, G. (2015). A Policy Making process Model for Public Organizations. Public policy, 1(3), 29-53. 
Babaei, S., \& Tavakoli, G. (2017). Deriving basic rationalities in public policy making process. Public Policy, $3(1), 63-82$.

Baldwin, T., Fitzgerald, M., Kitzinger, J., Laurie, G., Price, J., Rose, N., . . . Warwick, K. (2013). Novel neurotechnologies: Intervening in the brain. Nuffield Council on Bioethics.

Bremer, S., Millar, K., Wright, N., \& Kaiser, M. (2015). Responsible techno-innovation in aquaculture: Employing ethical engagement to explore attitudes to GM salmon in Northern Europe. Aquaculture, 437, 370-381. https://doi.org/10.1016/j.aquaculture.2014.12.031

Brom, F. W., Chaturvedi, S., Ladikas, M., \& Zhang, W. (2015). Institutionalizing ethical debates in science, technology and innovation policy: a comparison of Europe, India and China Science and Technology Governance and Ethics. Springer.

Burget, M., Bardone, E., \& Pedaste, M. (2017). Definitions and conceptual dimensions of responsible research and innovation: A literature review. Science and engineering ethics, 23(1), 1-19. https://doi.org/10.1007/s11948016-9782-1

Chen, C. (2006). CiteSpace II: Detecting and visualizing emerging trends and transient patterns in scientific literature. Journal of the American Society for information Science and Technology, 57(3), 359-377. https://doi.org/10.1002/asi.20317

Cobo, M. J., López-Herrera, A. G., Herrera-Viedma, E., \& Herrera, F. (2012). SciMAT: A new science mapping analysis software tool. Journal of the American Society for information Science and Technology, 63(8), 1609-1630. https://doi.org/10.1002/asi.22688

De Saille, S. (2015). Innovating innovation policy: the emergence of 'Responsible Research and Innovation'. Journal of Responsible Innovation 2(2), 152-168. https://doi.org/10.1080/23299460.2015.1045280

Flick, C. (2016). Informed consent and the Facebook emotional manipulation study. Research Ethics, 12(1), 14-28. https://doi.org/10.1177/1747016115599568

Forsberg, E.-M., Quaglio, G., O'Kane, H., Karapiperis, T., Van Woensel, L., \& Arnaldi, S. (2015). Assessment of science and technologies: Advising for and with responsibility. Technology in Society, 42, 21-27. https://doi.org/10.1016/j.techsoc.2014.12.004

Levidow, L., \& Neubauer, C. (2014). EU research agendas: Embedding what future? Science as Culture, 23(3), 397-412. https://doi.org/10.1080/09505431.2014.926149

Macnaghten, P., Owen, R., Stilgoe, J., Wynne, B., Azevedo, A., de Campos, A., . . . Frow, E. (2014). Responsible innovation across borders: tensions, paradoxes and possibilities. Journal of Responsible Innovation, 1(2), 191-199. https://doi.org/10.1080/23299460.2014.922249

Mohammadi, A., \& Mohammadi, S. (2021). Providing a conceptual model for the innovation strategy by using scenariobased technology roadmap in context of smart logistic system. Journal of Organizational Culture, Communications and Conflict, 25, 1-12.

Mohammadi, A., \& Mohammadi, S. (2021). A Conceptual Model for the Innovation Strategy in Terms of Uncertainty by a Scenario-Based Technology Roadmap. Экономика. Право. Общество, 6(1), 80-87.

Moral Muñoz, J. A., Herrera Viedma, E., Santisteban Espejo, A., \& Cobo, M. J. (2020). Software tools for conducting bibliometric analysis in science: An up-to-date review. Profesional de la Información, 29(1). https://doi.org/10.3145/epi.2020.ene.03

Owen, R. (2014). The UK Engineering and Physical Sciences Research Council's commitment to a framework for responsible innovation. Journal of Responsible Innovation, 1(1), 113-117. https://doi.org/10.1080/23299460.2014.882065 
Owen, R., Macnaghten, P., \& Stilgoe, J. (2012). Responsible research and innovation: From science in society to science for society, with society. Science and public policy, 39(6), 751-760. https://doi.org/10.1093/scipol/scs093

Owen, R., \& Pansera, M. (2019). Responsible innovation and responsible research and innovation Handbook on science and public policy. Edward Elgar Publishing.

Persson, O., Danell, R., \& Schneider, J. W. (2009). How to use Bibexcel for various types of bibliometric analysis. Celebrating scholarly communication studies: A Festschrift for Olle Persson at his 60th Birthday, 5, 9-24.

Ribeiro, B., Bengtsson, L., Benneworth, P., Bührer, S., Castro-Martínez, E., Hansen, M., . . Ott, C. (2018). Introducing the dilemma of societal alignment for inclusive and responsible research and innovation. Journal of responsible innovation, 5(3), 316-331. https://doi.org/10.1080/23299460.2018.1495033

Roco, M. C., Harthorn, B., Guston, D., \& Shapira, P. (2011). Innovative and responsible governance of nanotechnology for societal development Nanotechnology research directions for societal needs in 2020. Springer.

Stahl, B. C. (2013). Responsible research and innovation: The role of privacy in an emerging framework. Science and Public Policy, 40(6), 708-716. https://doi.org/10.1093/scipol/sct067

Stilgoe, J., Owen, R., \& Macnaghten, P. (2013). Developing a framework for responsible innovation. Research policy, 42(9), 1568-1580. https://doi.org/10.1016/j.respol.2013.05.008

Stilgoe, S., \& Guston, D. (2017). Responsible research and innovation. The handbook of science and technology studies. Cambridge.

Team, S. (2009). Science of Science (Sci2) Tool. Indiana University and SciTech Strategies.

Thapa, R. K., Iakovleva, T., \& Foss, L. (2019). Responsible research and innovation: a systematic review of the literature and its applications to regional studies. European Planning Studies, 27(12), 2470-2490. https://doi.org/10.1080/09654313.2019.1625871

Timmermans, J., Yaghmaei, E., Stahl, B. C., \& Brem, A. (2017). Research and innovation processes revisitednetworked responsibility in industry. Sustainability Accounting, Management and Policy Journal, 8(3), 307-334. https://doi.org/10.1108/SAMPJ-04-2015-0023

Van Eck, N. J., \& Waltman, L. (2010). Software survey: VOSviewer, a computer program for bibliometric mapping. Scientometrics, 84(2), 523-538. https://doi.org/10.1007/s11192-009-0146-3

Van Eck, N. J., \& Waltman, L. (2014). CitNetExplorer: A new software tool for analyzing and visualizing citation networks. Journal of informetrics, 8(4), 802-823. https://doi.org/10.1016/j.joi.2014.07.006

Von Schomberg, R. (2011). Towards responsible research and innovation in the information and communication technologies and security technologies fields. Available at SSRN: https://ssrn.com/abstract=2436399

Von Schomberg, R. (2012). Prospects for technology assessment in a framework of responsible research and innovation. Springer. 
Von Schomberg, R. (2013). A vision of responsible research and innovation. In R. Owen, J. Bessant \& M. Heintz (Eds.), Responsible innovation: Managing the responsible emergence of science and innovation in society (pp. 51-74). Wiley.

\section{(9) $(\mathbb{\theta} \Theta \Theta$}

(C) Attribution-NonCommercial-NoDerivatives 4.0 International (CC BY-NC-ND 4.0)

https://creativecommons.org/licenses/by-nc-nd/4.0/ 